\title{
The Process of Verbal Communication in Ethnic Malay and Batak: A Case Study
}

\author{
Nelyahardi \\ Department of Guidance and Counseling \\ Universitas Negeri Jambi, Indonesia \\ nelyahardi.fkip@unja.ac.id \\ Freddi Sarman \\ Department of Guidance and Counseling \\ Universitas Negeri Jambi, Indonesia \\ freddisarman@unja.ac.id
}

\author{
Hera Wahyuni \\ Department of Guidance and Counseling \\ Universitas Negeri Jambi, Indonesia \\ hera.wahyuni@ymail.com \\ Randani \\ Department of Guidance and Counseling \\ Universitas Riau Kepulauan, Indonesia \\ ramdani@fkip.unrika.ac.id
}

\begin{abstract}
Communication skills are the main requirements that must be mastered by the counselor in the individual counseling process. The success of the counseling process is determined by the counselor's communication skills, both verbal and nonverbal communication. Individual counseling processes are firmly rooted in the context of complex communication, an understanding of verbal and nonverbal communication becomes very important. The counselor must understand the cultural differences brought by the counselor and the client's culture so that the goals in the counseling process are achieved. The purpose of this study is to describe the verbal communication of Malay, and Batak counselors. This type of research is qualitative research with a descriptive approach, which is to describe or describe the phenomenon of the field in depth. Data collection in this study uses documentation in the form of a counselor's voice recording in the counseling process. Sound recordings in individual counseling have received permission from the counselee. The subjects in this study were counselors with Malay and Batak backgrounds. The results showed that the verbal communication of Malay and Batak counselors in the counseling process used the languages and dialects of their respective regions namely MJ counselors with Malay dialects and regional languages and RMD counselors with Batak dialects and regional.
\end{abstract}

Keywords: verbal communication, counselor, ethnic, malay and batak

\section{INTRODUCTION}

Data from the Indonesian Child Protection Commission (KPAI) Retno Listyarti KPAI Commissioner in education in the number of educational cases as of 30 May 2018 total 161 cases. With details as follows: (1) cases of brawl victims 23 (14.3\%), (2) cases of brawlers $31(19.3 \%)$, (3) cases of child victims of violence and bullying 36 (22.4\%), (4) cases perpetrators of violence and bullying $41(25.5 \%)$, and (5) cases of child victims of policy (extortion, expulsion, not taking exams, dropping out of school) 30 (18.7\%) (idntimes.com).

Based on these data, counseling service is very helpful for students to overcome the problem, counseling service can be a tool to prevent "normal" problems from becoming more serious which results in delinquency, failure and emotional disturbance (Hornby, Hall, \& Hall, 2003). Furthermore, according to Onyango, Aloka, \& Rakuru, (2018). Guidance and counseling can help students develop self-esteem and make students feel that they are recognized and can look at themselves positively. This is consistent with the research by Daunhauer (2014) in America which revealed that students undergoing guidance and counseling showed a change in attitude.

Furthermore, the results of Khofifah, A., Sano, A., \& Gratitude, Y (2017) types of problems submitted by students to counselor teachers at school can be divided into 4 areas of guidance namely: (1) the field of career guidance $52.6 \%$; (2) the field of social guidance $30 \%$; (3) the field of tutoring $42 \%$; and (4) the field of personal guidance 32.8\%. The Renuka study (2013) established that counseling in India was effective in resolving adjustment difficulties, such as appetite disorders, concentration problems, and depression which were very common among new students who were accepted.

Based on these data, the role of counselors is needed in schools to realize national education goals. The presence of counselors in schools will help students who experience difficulties in various problems, especially problems relating to learning, personal, social and career. One service that can be used to help students overcome their problems is individual counseling services. Egbochuku (2002) defines counseling as a 'face-to-face' situation where a counselor, based on his training and skills, helps clients to deal with, understand, clarify, resolve and resolve adjustment/problem

Individual counseling is one of the special ways to help others who involve certain skills for special purposes (Geldard \& Geldard, 2005). Individual counseling involves a professional relationship that is both supportive and very dependent on the quality of the counselor's personality. In conducting counseling practices, counselors rely on the use of some skills, one of which is the ability to communicate which is a micro counseling skill, in addition to various other skills (Geldard \& Geldard, 2005). According to Jones (2008), there are two main categories of counseling skills, namely communication and acting skills, as well as mental skills.

Communication skills are the main requirements that must be mastered by the counselor in the individual counseling process. According to Okun (in Rantanen \& Anti, 2014), two main communication techniques are characteristic of client-centered counseling, namely 
reflection skills and questioning skills. Auni, Jepchirchir and Ong'unya (2014) research in Kenya determined that the lack of facilities, poorly trained teachers and ineffective strategies inhibited students' social inequality. Furthermore, Sumarto (2016) explains the counselor's communication skills to determine the success or failure of the counseling process.

The counselor respects the diversity of the client and does not impose the values that the counselor brings to the client (Corey, 2017). Gibson \& Mitchell (2011) Professional counselors need to remember that differences in ethnicity, dialect, and language between counselors and liens greatly influence the success of the counseling process. The counselor must understand the cultural differences brought by the counselor and the client's culture so that the goals in the counseling process are achieved.

Based on this, effective counselor communication skills are needed to assist students to have an effective everyday life (KES). The range of counselor communication in the counseling process is very broad, so this study will be limited to category first the communication that the counselor uses in the counseling process is the verbal communication of the counselor in the individual counseling stage.

Second communication skills in the six stages of individual counseling that are intended are namely paraphrase, reflecting feelings, interpretation, summarization, clarification and open and closed questions. Third counselor is a professional in the field of guidance and counseling who has been educated in PPK / PPGBK for one year. Fourth the cultural background of the counselor comes from the Malay and Batak tribes. The purpose of this study is to describe the verbal communication of Malay and Batak counselors.

\section{METHOD}

This study aims to describe the construction of verbal communication skills in Malay and Batak counselors. This research is categorized as a type of qualitative research with a descriptive approach. Qualitative research is used to describe the phenomena that exist in the field in depth.

This research is a cross-cultural study, where the research site is conducted in a counselor area with a different background, namely for counselors from the Jambi Malays, Medan Batak Tribes and Tribes. The time of the study was conducted in July - August 2019. The subjects in this study were two counselors with the background of the Jambi Malays and Medan Batak who had academic qualifications as a counselor and had done multicultural counseling.

The presence of researchers in this study as data collectors and analyze data and report research results. The subjects of the study were two counselors with Malay and Batak backgrounds. The three research subjects are MJ counselors and RMD counselors. In this research, the determination of the research subject is based on obtaining permission as well as its availability being the subject of research with the title of the verbal communication construction of the Malay and Batak counselors.

\section{RESULT AND DISCUSSION \\ Description of Research Subjects}

The subjects in this study had previously been determined by using subject criteria, namely an individual who already had an academic qualification as a counselor who had conducted multicultural counseling with students of different ethnicities (BK teachers with Malay ethnic backgrounds, students with ethnic backgrounds other than Malay). The following are the subjects in this study. The first research subject is MJ Counselor, MJ female gender works as counselor Malay ethnic, Jambi City. second research subject Male RMD counselors work as counselor Batak ethnic.

\section{Verbal Communication Counselor inside Counseling Process}

Communication is a process of delivering information or messages in the form of ideas, ideas, thoughts from one individual (communicator) to another individual (communicant). Communication is very important for human survival, where communication is used as a tool to interact with other individuals in social contexts. Communication will be considered successful if what is conveyed by the communicator is received the same or in the same meaning by the communicant.

In the implementation of multicultural counseling, effective and sensitive counselors are needed for the diverse cultures brought by the counselee, this is because multicultural counseling is vulnerable to problems when there are two cultural encounters between counselor and counselee. Therefore, the counselor must understand and master the theory and have the skills to provide services that are effective and sensitive to the cultural differences of the counselor. Following are the results of research on the subject regarding verbal communication Counselors in Individual Counseling.

Communication skills respond verbally in the counseling process is the core of individual counseling activities. There are six verbal skills in the counseling process namely paraphrase, reflecting feelings, interpretation, summarization, clarification and open and closed questions. The results of observing the counseling process obtained the following results:

\section{Paraphrase}

The results of observing the counseling process of the MJ counselor's verbal response are:

"cuman kendalanya kamu takut pisah sama orangtua. Terus takut hantu, kenapa memangnya itukan ibaratnyakan gossip-gosip gak ada sebenarnya itu. Jadi kendala kamu Cuma takut pisah sama orangtua ya begitu?" (MJ, menit ke 24).

The meaning of the statement is that MJ's counselor asked the counselee "So the obstacle that you are experiencing is just being afraid of being separated from your parents, is it really like that? (with intonation of voice asking), Next to the ghost problem, it's actually not there, it's just gossip". For RMD counselors the observations are:

"aa....., tadi kamu katakan kamu sering menonton adegan-adegan kekerasan, berbau seksualitas, 
horror dan lain-lain kan...!", a... bapak mau tau apakah kamu sering menonton itu, atau dimana kamu menonton? (RMD, Menit ke10).

The meaning of the statement is that the RMD counselor asked the counselee "You told me that when you watch often watching programs related to sex, horror, and others, is it really like that? I want to ask where did you watch the sex-related program? (with intonation asking).

\section{Reflecting Feelings}

The results of observing the counseling process with MJ for reflection of feelings are:

"oh...jadi karena ada isu-isu ada hantu kamu takut?" (MJ, Menit ke 8).

The meaning of the statement is MJ's counselor uses a feeling reflection technique in the form of "are you afraid because there is an issue in the place of ghosts? For RMD counselors the reflection of feelings is:

"o...., maksudnya disini susah dilupakan hal-hal buruk itu tadi ya?" (RMD, Menit ke 37).

The meaning of the statement is the RMD counselor "so you have a hard time forgetting unpleasant incidents"

\section{Interpretation}

The results of observing the counseling process with MJ include:

"untuk menjadi seorang polwan memang keras, apalagi kamu mau masuk TT (nama sekolah), tentu kamu sudah tau kalau masuk TT itu, memang harus tinggal di asrama, sangat disayangkan Cuma garagara isu ada hantu kamu menjadi tidak semangat"(MJ, Menit ke 45).

The meaning of the statement is MJ's counselor "to be a female police officer does require a lot of effort, then you already know that to enter a TT school (short for the name of a school in the Jambi area) does have to live in a dormitory, unfortunately, your motivation is low because there the issue of ghosts ". For RMD counselors the observations are:

" oke sekarang yang mau bapak tanyakan ke kamu, inikan ibaratnya, e... kejadian yang itu terekam sangat nyata dalam pikiran kamu ya," (RMD, Menit ke 48).

The meaning of the statement is that the RMD counselor interpreted "so the incident about the sexrelated film image makes it hard for you to forget, is it really like that?"

\section{Summarization}

The results of observing the counseling process with $\mathrm{MJ}$ are:

"kamu tidak yakin dengan kemampuanmu" (MJ, Menit ke 20).

The meaning of the statement is that MJ's counselor concluded while "you are not sure of your abilities?" For RMD counselors the observations are: "jadi dampaknya dua itu lah yah, selain mengganggu pikiran saat belajar karena terlintasan-terlintasan, yang kedua kamu juga menjadi lebih kawatir ya?? Seperti itu ya? (RMD, Menit ke 53).

The meaning of the statement is the RMD counselor that is "so there are two impacts, the first disturbing the mind while studying and the second makes you more worried, is it really like that?"

\section{Clarification} MJ are:

The results of observing the counseling process with

"jadi kamu berfikir bahwa menjadi polwan itu payah?" (MJ, Menit ke 30).

The meaning of the statement is MJ's counselor that is "you think it is difficult to be a policewoman, is it really like that?" For RMD counselors the observations are:

"oke, a. dalam arti dari kejadian itu pernah juga itu terlintas dalam bayangan kamu itu tadi? (RMD, Menit ke 23).

The meaning of the statement is that the RMD counselor is "mean that such an incident has ever crossed your mind?"

\section{Open and Closed Questions} MJ are:

The results of observing the counseling process with

"terus, kenapa kamu kepengen masuk TT?" (MJ,

Menit ke 15)

" itu kendalamu" (MJ, Menit ke 8).

The meaning of the statement is MJ's counselor namely: "why do you want to go to TT? (the name of the school in the Jambi area), then "is this your problem?" For RMD counselors, the observations are:

"a... sekarang ini dampak dari tayangan-tayangan yang tampil seketika di pikiran kamu apa kira-kira dampaknya dalam diri kamu?" (RMD Menit ke 16).

"pernah terfikir apakah "Saya" punya kelainan pribadi? (RMD, Menit ke 22).

The meaning of the statement is the RMD counselor namely: "In your opinion, what are the consequences you feel?" Furthermore, "have you ever thought of having a personality disorder?

\section{CONCLUSION}

Based on the findings and discussion of research results, it can be concluded in the process of individual counseling for Malay and Batak tribal counselors, the verbal communication of counselors in individual counseling using regional dialects and their respective regional languages. Where MJ counselors with the Jambi Malay ethnic group use the Malay language and its dialect. Furthermore, the RMD counselor with the Batak Medan tribe uses the Batak language and its dialect.

However, this does not hamper the counseling process, wherein the counseling process between the 
counselor MJ and RMD the counselee openly and smoothly tells the problems they experienced. Based on the results of the research, discussion and conclusions that have been put forward, there are a number of suggestions that can be submitted as a follow-up to this research, which can be used as a basis for further research by expanding variables and research subjects, such as research development on other variables regarding the verbal communication of counselors with differences other culture.

\section{REFERENCES}

[1] Auni, R., Jepchirchir, R \& Ong'unya, E. (2014) Determinants of Guidance and Counseling in Addressing Students' Social Adjustment in Secondary Schools in Siaya District of Kenya. International Journal of Humanities and Social Sciences. 4(4) pp. 69-76.

[2] Corey, Gerald. 2017. Theory and Practice of Counseling and Psychotherapy (Tenth Edition). Boston: Cengage Learning.

[3] Egbochuku, E. O. 2002. The Nigerian Teacher's Ethos and Educational Communication: Suggestion for enhancing credibility in the classroom. The Counsellor An official Journal of the Counselling Association of Nigeria (CASSON). 19 (1): pp.18-24.

[4] Gelderd, K., \& Geldard, D. 2005. Practical Counselling Skills: An Integrative Approach.
[5] Gibson, Robert, L \& Mitchell, Marianne, H. 2011. Introduction to Counseling and Guidance. di Terjemahkan Oleh Yudi Santoso. Yogyakarta: Pustaka Pelajar.

[6] Hornby, G., Hall, C., \& Hall, E. 2003. Counseling Pupils in Schools: Skills and strategies for teacher. London: Routledge Falmer.

[7] Jonnes. Richadr N. 2008. Basic Counselling Skills: A helper's manual (Second edition). London: SAGE Publication

[8] Khofifah, A., Sano, A., \& Syukur, Y. 2017. Permasalahan yang Disampaikan Siswa Kepada Guru BK/ Konselor. Jurnal EDUCATIO (Jurnal Pendidikan Indonesia). 3(1). Pp. 45-52.

[9] Listyarti. 2018. Berita Online. IDNTIMES.com.

[10] Rantanen, Anti. 2014. Development Of Methodology For Assessing Counseling Interaction: Developing the counselor response observation system and assessing applicability of heart rate variability to the measurement of client emotions during verbal reporting". Acta University of Oulu. E 150.

[11] Renuka, D. 2013. Effect of Counseling on the Academic Performance of College Students. Journal of Clinical and Diagnostic Research (7) pp.1086-1088.

[12] Sumarto. 2016. Komunikasi Interpersonal dalam Proses Konseling. Jurnal Pendidikan dan Hukum Islam. Vol 10 (1).

[13] Tepper, Donalt. T., \& Haase Richard. F. 2001. Verbal and Nonverbal Communication of Facilitative Conditions. American Psychological Association xviii, pp. 211-23. 